\title{
Interleukin 2 Mediates Stimulation of Complement C3 Biosynthesis in Human Proximal Tubular Epithelial Cells
}

\author{
Ricardo A. Brooimans, Alexander P. A. Stegmann, Wim T. van Dorp, Arnoldus A. J. van der Ark, \\ Fokko J. van der Woude, Leendert A. van Es, and Mohamed R. Daha \\ Department of Nephrology, University Hospital, Leiden, The Netherlands
}

\begin{abstract}
Previous reports have suggested the production of complement components $\mathrm{C4}, \mathrm{C2}$, and factor $\mathrm{B}$ by renal tissue. However, the cells involved in production of complement have not been identified. In this study metabolic labeling experiments demonstrated that human proximal tubular epithelial cells (PTEC) synthesize a $180-\mathrm{kD}$ precursor of $\mathrm{C} 3$ that is secreted after proteolytic cleavage into a disulphide linked two-chain molecule as found in plasma. C3 present in culture supernatants of PTEC was functionally active, however, during the culture period there was a partial inactivation of the $\mathbf{C} 3$ molecule as assessed by hemolytic titration. Recombinant IL-2 enhances the rate of C3 synthesis in a dose-dependent manner reaching maximal stimulation at doses of $200-400 \mathrm{U} / \mathrm{ml}$ IL-2. Northern blot analysis demonstrated a 5.2-kb C3 mRNA species present in PTEC that was increased within $24 \mathrm{~h}$ of IL-2 treatment. IL-2-induced enhancement of $\mathrm{C} 3$ production by PTEC could be neutralized with specific antibodies to IL-2. This study demonstrates that C3 synthesis in PTEC is upregulated by IL-2, the major cytokine produced by activated T cells. (J. Clin. Invest. 1991. 88:379-384.) Key words: complement synthesis $\bullet$ kidney $\bullet$ lymphokines
\end{abstract}

\section{Introduction}

The third component of complement (C3) is an important effector in immune response pathways because of its multiple interactions with numerous serum proteins, cell surface molecules, and foreign proteins (1). C3 is produced intracellularly as a single chain precursor of $180 \mathrm{kD}$ (pro-C3), which is processed by proteolytic cleavage into the native two-chain molecule, comprised of a 110-kD $\alpha$ chain and a 75-kD $\beta$ chain (2).

C3 has been shown to be synthesized mainly in liver hepatocytes (3). However, C3 is also produced by several other cell

The data in this paper were presented in part at the 74th annual meeting of the Federation of the American Society for Experimental Biology, 5 June 1990 (Brooimans, R. A., A. P. A. Stegmann, W. T. van Dorp, F. J. van der Woude, L. A. van Es, and M. R. Daha. 1990. Synthesis of complement $\mathrm{C} 3$ in human proximal tubular epithelial cells is regulated by IL-2. FASEB [Fed. Am. Soc. Exp. Biol.] J. 4:1871a. (Abstr.).

Address correspondence and reprint requests to Ricardo A. Brooimans, Department of Nephrology, Building 1, C3-P, University Hospital, Rijnsburgerweg 10, 2333 AA Leiden, The Netherlands.

Received for publication 7 September 1990 and in revised form 23 April 1991.

J. Clin. Invest.

(c) The American Society for Clinical Investigation, Inc.

0021-9738/91/08/0379/06 \$2.00

Volume 88, August 1991, 379-384 types including: monocytes/macrophages (4-6), fibroblasts (7), endothelial (8-10), and epithelial cells (11). It has been suggested that this extrahepatic synthesis in tissues of $\mathrm{C} 3$ as well as of other complement components may play an important role in local inflammatory processes. Recently, mRNA transcripts for $\mathrm{C} 4$ and factor $\mathrm{B}$ have been demonstrated in normal human kidney (12), and transcripts for C2, C3, C4, and factor B were detected in murine kidneys (13). Complement components, such as $\mathrm{C} 3 \mathrm{~b}$ and $\mathrm{C} 4 \mathrm{~b}$, can also be present as part of immune deposits in kidneys of patients with glomerulonephritis (14), but it is unclear whether these activation products are derived from the circulation or have been produced locally. In Lupus Nephritis, marked differences in expression of complement mRNA at local sites of inflammation suggest that local complement production may play a role in the pathogenesis of chronic glomerulonephritis (13). This is to our knowledge the first study to show that human proximal tubular epithelial cells (PTEC) ${ }^{1}$ synthesize and secrete $\mathrm{C} 3$ in vitro, and that an enhanced production of $\mathrm{C} 3$ occurs in the presence of recombinant IL-2.

\section{Methods}

Reagents. Antipain, chymostatin, epidermal growth factor (EGF), hydrocortisone, insulin, leupeptin, pepstatin A, selenate, Staphylococcus aureus crude cell suspension formalin-fixed, tri-iodothyronine, transferrin, trypsin (Sigma Chemical Co., St. Louis, MO), Vitrogen bovine dermal collagen type 1 (Collagen Corp., Palo Alto, CA), DMEM, Ham's F12 medium (Seromed, Biochrom K.G., Berlin, FRG), fetal calf serum, newborn calf serum (HyClone Laboratories Inc., Logan, Utah), streptavidin peroxidase conjugate (Zymed Laboratories Inc., San Francisco, CA), L- $\left[{ }^{35}\right.$ S $]$ methionine (Amersham Corp., Arlington Heights, IL), recombinant IL-2 (Sanbio, Uden, The Netherlands), and sheep erythrocytes $\left(E^{S}\right)$ (National Institute of Public Health, Bilthoven, The Netherlands) were purchased as indicated. Normal human serum (NHS) was separated from clotted blood samples from healthy donors and divided into aliquots and stored at $-70^{\circ} \mathrm{C}$. C3-deficient serum was obtained from a patient with an inherited deficiency of the third component of complement (15). Half-isotonic Veronal buffered saline (VBS, $\mathrm{pH} 7.5$ ) containing $0.05 \%$ gelatin, $0.5 \mathrm{mM} \mathrm{MgCl}$ and $0.15 \mathrm{mM} \mathrm{CaCl}_{2}$, and $3 \%$ dextrose $\left(\mathrm{DGVB}^{++}\right)$was used as diluent in hemolytic assays. Polyclonal goat IgG anti-human C3 was prepared from goat anti-human C3 serum as described (10). Monoclonal mouse anti-human C3 antibodies (16) were kindly provided by Dr. E. Hack (Central Laboratory for Blood Transfusion, Amsterdam, The Netherlands). Polyclonal antibodies against human IL-2 were produced at our own institute by immunizing a rabbit with recombinant IL-2 in complete Freund adjuvant. IgG was purified from the antiserum and this was used to prepare

1. Abbreviations used in this paper: $\mathrm{DGVB}^{++}$, half-isotonic Veronal buffered saline (VBS) containing $0.05 \%$ gelatin, $0.15 \mathrm{mM} \mathrm{CaCl}_{2}+0.5$ $\mathrm{mM} \mathrm{MgCl}$, and 3\% dextrose; EC, human endothelial cells; NHS, normal human serum; PTEC, proximal tubular epithelial cells; TCGF, T cell growth factor. 
$\mathrm{F}\left(\mathrm{ab}^{\prime}\right)_{2}$ fragments by pepsin digestion (17). Monoclonal antibodies directed against the adenosine-deaminase binding protein (ADBP) of PTEC, designated 1071 and 1072 (18), were generously donated by Dr. Dinjens (University Hospital, Maastricht, The Netherlands). Human complement C3 cDNA probe C3.A1 was a kind gift from Dr. B. F. Tack (Research Institute of Scripps Clinic, La Jolla, CA).

Proximal tubular epithelial cell cultures. PTEC were cultured following the protocol as described by Detrisac et al. (19) in serum-free Dulbecco's modified Eagle's medium/Ham's F12 medium 1:1 supplemented with insulin $(5 \mu \mathrm{g} / \mathrm{ml})$, selenium $(5 \mathrm{ng} / \mathrm{ml})$, transferrin $(5 \mu \mathrm{g} /$ $\mathrm{ml})$, triiodothyronine $(4 \mathrm{pg} / \mathrm{ml})$, epidermal growth factor EGF $(10 \mathrm{ng} /$ $\mathrm{ml}$ ), and hydrocortisone $(36 \mathrm{ng} / \mathrm{ml})$ on a matrix of bovine dermal collagen type 1 matrix and FCS proteins. Explant cultures were obtained from kidneys not suitable for transplantation because of technical reasons or from healthy tissue of nephrectomy specimens obtained after operation.

The kidney cell population obtained after culturing was characterized by light microscopy and immunofluorescence using various MAbs as described (18). The MAbs used were anticytokeratin (RGE 53; Eurodiagnostics, Apeldoorn, The Netherlands), anti-epithelial membrane antigen (EMA; Dako, Glostrup, Denmark), and two MAbs directed against the ADBP, designated 1071 and 1072. PTEC monolayers obtained between passage 2 and 6 were cultured using multi-well tissue culture plates (Costar Corp., Cambridge, MA). The cells were rinsed and cultured for different time intervals in medium alone or in medium containing various concentrations of recombinant IL-2. At the end of the experiments culture supernatants were collected, centrifuged, and stored at $-20^{\circ} \mathrm{C}$. PTEC were trypsinized to determine the number of cells, using a Coulter counter (Coulter Electronics Ltd., Luton, England). The viability and number of the IL-2-treated PTEC during the experimental period did not differ from control cells.

Biosynthetic labeling and immunoprecipitation. Biosynthetic labeling experiments were performed by incubating PTEC monolayers in methionine-free DMEM containing $\left[{ }^{35} \mathrm{~S}\right]$ methionine $(500 \mu \mathrm{Ci} / \mathrm{ml})$ for $2 \mathrm{~h}$. At the end of the pulse period, monolayers were rinsed and either lysed in buffer, containing $20 \mathrm{mM}$ Tris, $10 \mathrm{mM}$ EDTA, $100 \mathrm{mM} \mathrm{NaCl}$, $0.5 \% \mathrm{NP}-40$, antipain $(1 \mu \mathrm{g} / \mathrm{ml})$, pepstatin $\mathrm{A}(1 \mu \mathrm{g} / \mathrm{ml})$, chymostatin (1 $\mu \mathrm{g} / \mathrm{ml})$, and leupeptin $(1 \mu \mathrm{g} / \mathrm{ml})$, or transferred to medium containing $\sim 1000$-fold excess of cold methionine and incubated for various time periods. At the end of each chase interval, extracellular media were harvested and monolayers lysed. Before immunoprecipitation, media and cell lysates were preabsorbed for four times at $4^{\circ} \mathrm{C}$ with $100 \mu \mathrm{l}$ of $10 \%$ (vol/vol) formalin-fixed Staphylococcus aureus, and then $5 \mu \mathrm{l}$ of mouse MAb directed against human $\mathrm{C} 3$ was added to the samples. After incubation for $16 \mathrm{~h}$ at $4^{\circ} \mathrm{C}$, antibody-antigen complexes were recovered by using $100 \mu \mathrm{l}$ of $10 \% \mathrm{~S}$. aureus. The immunoprecipitates were centrifuged, washed, and subjected to SDS-PAGE (7\%) under reducing conditions. The gels were fixed, impregnated with Amplify (Amersham Corp.), dried, and exposed at $-70^{\circ} \mathrm{C}$ to Kodak XAR-5 films (Eastman Kodak, Rochester, NY).

Sandwich ELISA for the detection and quantification of C3. C3 was quantitated by sandwich ELISA. Wells in microtiter plates (Titertek Flow Laboratories, Zwanenburg, The Netherlands) were coated with affinity purified goat anti-human $\mathrm{C} 3$ for $2 \mathrm{~h}$ at $37^{\circ} \mathrm{C}$. After washing, samples were incubated in the wells at a $1: 20$ dilution for $1 \mathrm{~h}$ at $37^{\circ} \mathrm{C}$. The wells were subsequently treated with biotin-labeled goat anti-human C3, peroxidase-labeled streptavidin, and $o$-phenylene-diamine as a substrate. Between the incubation steps the wells were thoroughly washed with PBS $/ 0.05 \%$ Tween 20 . The amount of reacted substrate was determined using a Titertek Multiskan (Titertek Flow Laboratories, Zwanenburg, The Netherlands) at OD492 after the reaction was stopped with $1 \mathrm{~N} \mathrm{H}_{2} \mathrm{SO}_{4}$. A standard curve was constructed using dilutions of NHS with known concentrations of C3. The amount of $\mathrm{C} 3$ in the samples was determined from the standard curve.

Hemolytic assay for C3. Samples to be tested for the presence of

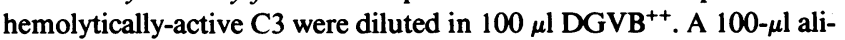
quot of sheep erythrocytes $\left(E^{8}\right)$ in $D G V B^{++}\left(1.10^{8}\right.$ cells $\left./ \mathrm{ml}\right)$, optimally sensitized with rabbit anti- $E^{s}$ antibodies, was then added together with a 1:50 dilution of C3-deficient serum. After an incubation of $60 \mathrm{~min}$ at $37^{\circ} \mathrm{C}$ in a shaking waterbath, hemolysis was measured spectrophotometrically. The number of effective molecules was expressed as $\mathrm{Z}$ values as described by Borsos et al. (20). $\mathrm{Z}$ was plotted against dilutions or concentrations of $\mathrm{C} 3$ sources.

$R N A$ extraction and Northern blot analysis of C3 $\mathrm{mRNA}$ in PTEC. Total cellular RNA was extracted from monolayers by lysis with guanidin thiocynate and isolated by cesium chloride density gradient ultracentrifugation (21). $20 \mu \mathrm{g}$ of total RNA were separated on a formaldehyde-containing agarose gel and blotted to nitrocellulose filters (Gene Screen Plus; DuPont, Wilmington, DE). Gel electrophoresis, RNA transfer, and hybridization of blots were done by standard techniques (22). The utilized cDNA probes were radiolabeled with $\left[{ }^{32} \mathrm{P}\right]$ by random primed labeling (23). The intensity and area of density of the relevant bands on the autoradiograms were determined with an UltroScan XL (LKB, Woerden, The Netherlands).

Binding assay of ${ }^{125}$ I-IL-2 to monolayers of cells. Pure rIL-2 was labeled with $\mathrm{Na}^{125} \mathrm{I}$ (Amersham Corp.) using chloramine-T, and the radioligand was purified by gel filtration chromatography. For binding experiments, replicate cultures were incubated with $20 \mathrm{nM}{ }^{125} \mathrm{I}-\mathrm{IL}-2$ alone or in the presence of unlabeled IL-2 $(20-200 \mathrm{nM})$ for $1 \mathrm{~h}$ at $4^{\circ} \mathrm{C}$. Monolayers were subsequently washed three times and assessed for bound radioactivity. Binding studies were performed using monolayers of PTEC, and human endothelial cells (EC) isolated from umbilical cords as described previously (10).

\section{Results}

In a preliminary study it was found that in conditioned medium of human PTEC, complement component $\mathrm{C} 3$ was detectable as assessed by ELISA (data not shown). To determine whether this $\mathrm{C} 3$ is synthesized de novo, confluent monolayers of PTEC were metabolically labeled with $\mathrm{L}-\left[{ }^{35} \mathrm{~S}\right]$ methionine for $2 \mathrm{~h}$; the cultures were then incubated in medium containing unlabeled methionine. At timed intervals C3 was immunoprecipitated from the supernatants and cell lysates, and analyzed by SDS-PAGE under reducing conditions and autoradiography. As shown in Fig. 1 (lanes 1-4), C3 was synthesized as a single chain precursor of $\sim 180 \mathrm{kD}$ (proC3). The gradual disappearance of pro $\mathrm{C} 3$ from the cellular material and the concominant extracellular appearance of disulphide-linked twochain native C3 (lanes 5-8), suggests a conversion by limited proteolysis to native functional $\mathrm{C} 3$, as also described in monocytes (6), hepatocytes (24), and fibroblasts (25). The extra C3 forms of $40-45 \mathrm{kD}$ probably represent products of protease digestion or autolytic fragmentation (26).

To determine the functional activity of $\mathrm{C} 3$ produced by PTEC in vitro, culture supernatants were used in a hemolytic C3 titration assay. Culture supernatants of different PTEC cultures that had been in culture for $48 \mathrm{~h}$ were harvested and pooled. The amount of $\mathrm{C} 3$ in this pool was assessed by ELISA. Subsequently the pool was diluted in $\mathrm{DGVB}^{++}$and titrated in a hemolytic assay using $\mathrm{C} 3$-deficient serum. The functional activity of PTEC-C3 was compared with dilutions of pooled NHS with the same amounts of $\mathrm{C} 3$, as depicted in Fig. $2 a$. The titration curve was linear and demonstrated a difference of $27 \%$ between the functional activities of $\mathrm{C} 3$ present in NHS and C3 present in culture supernatants of PTEC on a weight basis (Fig. 2 a). Because of this difference, culture supernatants of PTEC were harvested at different time points and assessed for the concentrations of $\mathrm{C} 3$ and for hemolytically-active $\mathrm{C} 3$ to study a possible inactivation of the $\mathrm{C} 3$ molecule during the culture period. There was a time-dependent linear increase in both the amount of $\mathrm{C} 3$ and the number of effective $\mathrm{C} 3$ molecules pro- 
INTRACELLULAR

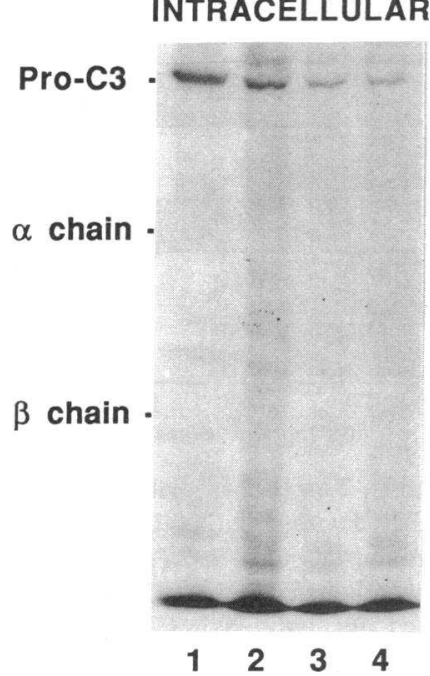

\section{EXTRACELLULAR}

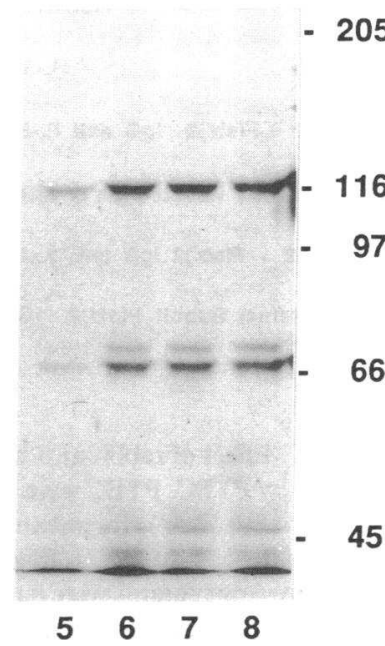

Figure 1. Pulse-chase experiment for $\mathrm{C} 3$ synthesis in PTEC. Monolayers of PTEC were incubated at $37^{\circ} \mathrm{C}$ in the presence of $\left[{ }^{35} \mathrm{~S}\right]-$ methionine $(500 \mu \mathrm{Ci} / \mathrm{ml})$ for $2 \mathrm{~h}$, rinsed, and transferred to medium containing unlabeled methionine, and the incubation was continued. Lysates and culture supernatants were harvested at time 30 (lanes 1 and 5), 60 (lanes 2 and 6), 120 (lanes 3 and 7), and 180 min (lanes 4 and 8 ) thereafter, and were immunoprecipitated with a monoclonal antibody to human C3. Immunoprecipitates were analyzed on $7 \%$ SDS-PAGE gel under reducing conditions and fluoroautoradiography. Numbers on the right are in $\mathrm{kD}$.

duced by PTEC (Fig. 2 b). However, the ratio between hemolytically active $\mathrm{C} 3$ and total $\mathrm{C} 3$ protein showed a steady decline between 24 and $72 \mathrm{~h}$, suggesting a partial inactivation of $\mathrm{C} 3$ during the culture period.
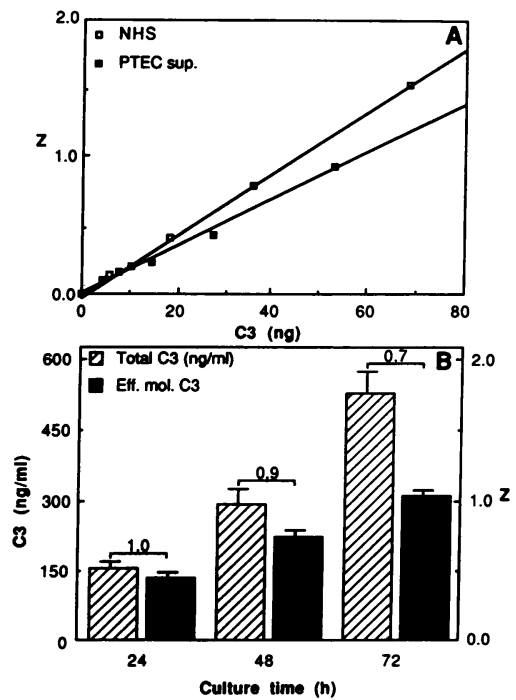

Figure 2. Hemolytic titration of PTEC culture supernatants for $\mathrm{C} 3 .(A)$ Supernatants of various PTEC cultures were pooled, the amount of C3 was assessed with ELISA, dilutions were made in $\mathrm{DGVB}^{++}$, and assessed for functional C3, using C3-deficient serum as described in Methods. Functional activity was compared with dilutions of pooled NHS containing a known concentration of C3. (B) Secretion of hemolytically active $\mathrm{C} 3$ and $\mathrm{C} 3$ protein by PTEC. Replicate cultures were incubated for 24,48 , and $72 \mathrm{~h}$; subsequently, culture supernatants were collected and assessed for the amount of $\mathrm{C} 3$ by ELISA and for functionally active $\mathrm{C} 3$, using $\mathrm{C} 3$-deficient serum as described in Methods. The ratios of hemolytically-active C3 as compared with total $\mathrm{C} 3$ protein for each time point are also depicted. The data are expressed as the mean $\pm \mathrm{SD}$ of duplicate determinations of triplicate cultures.

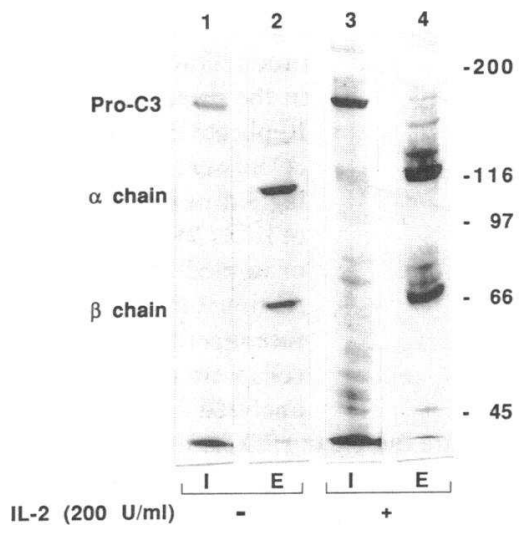

Figure 3. Effect of IL-2 on synthesis of $\mathrm{C} 3$ in human PTEC. Confluent cells were washed and incubated with IL-2 $(200 \mathrm{U} / \mathrm{ml})(+)$ or in medium alone $(-)$ for $24 \mathrm{~h}$ and then pulselabeled with $\left[{ }^{35} \mathrm{~S}\right]$ methionine for $2 \mathrm{~h}$ in the absence of stimulus. Cell lysates (intracellular [I], lanes 1 and 3) and culture supernatants (extracellular $[E]$, lanes 2 and 4 ) were immunoprecipitated with MAbs to $\mathrm{C} 3$ and the products were analyzed by SDS-PAGE analysis under reducing conditions and fluoroautoradiography. Numbers on the right are in $\mathrm{kD}$.

C3 production by PTEC was increased after treatment with conditioned medium of mitogen and PMA-stimulated PBMC, so called, $T$ cell growth factor (TCGF) (data not shown). Because the main constituent of TCGF is IL-2, monolayers of PTEC were cultured for $24 \mathrm{~h}$ in the presence of recombinant IL-2 $(200 \mathrm{U} / \mathrm{ml})$ or in medium alone and then pulse labeled with $\left[{ }^{35} \mathrm{~S}\right]$ methionine. Cell lysates and extracellular media were immunoprecipitated with a MAb specific for human $\mathrm{C} 3$ and the products analyzed by SDS-PAGE and autoradiography. IL2 enhanced the synthesis of $\mathrm{C} 3$, as judged by amounts of intracellular and extracellular proteins at the end of the pulse period (Fig. 3). The stimulation of $\mathrm{C} 3$ synthesis occurred in a dose-dependent fashion, and a 2.5 -fold increase was observed with a dose of $400 \mathrm{U} / \mathrm{ml} \mathrm{IL-2} \mathrm{(Fig.} \mathrm{4).} \mathrm{However,} \mathrm{the} \mathrm{upregulation} \mathrm{of}$ C3 synthesis between $200 \mathrm{U} / \mathrm{ml}$ and $400 \mathrm{U} / \mathrm{ml} \mathrm{IL-2} \mathrm{was} \mathrm{not}$ significant, therefore, $200 \mathrm{U} / \mathrm{ml} \mathrm{IL-2}$ was used in the following stimulation experiments. The kinetics of $\mathrm{C} 3$ production, as depicted in Fig. 5, showed a linear increase in the amount of $\mathrm{C} 3$ production. After treatment with IL-2 $(200 \mathrm{U} / \mathrm{ml})$ the amount of $\mathrm{C} 3$ was significantly increased by $80 \%$.

To indicate whether IL- 2 is mediating $\mathrm{C} 3$ synthesis at a preor posttranslational level, analysis of $\mathrm{C} 3 \mathrm{mRNA}$ transcripts was performed by Northern blotting. PTEC monolayers were incubated for various time periods with IL- 2 or medium alone. Then total RNA was isolated from each culture and $20 \mu \mathrm{g}$ of RNA were electrophoresed, blotted onto nitrocellulose, and C3 mRNA transcripts were detected by hybridization using a specific cDNA probe. As a control, the amount of $\beta$-actin mRNA

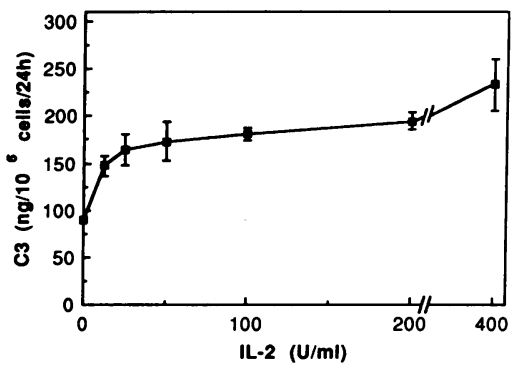

Figure 4. Effect of increasing concentrations of IL-2 on the production of $\mathrm{C} 3$ by PTEC in culture. Confluent cells were cultured for $72 \mathrm{~h}$ and subsequently, culture supernatants were collected and assessed for C3 protein by ELISA. The data are

expressed as the mean $\pm \mathrm{SD}$ of duplicate measurements of triplicate cultures. 


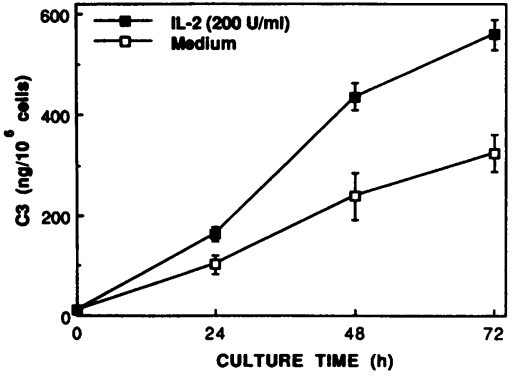

and the number of cells. Values are the mean \pm SD for duplicate determinations of triplicate cultures.

in IL-2-treated or -untreated cells was also determined. The Northern blot analysis (Fig. 6) demonstrated the presence of a full length $5.2 \mathrm{~kb}$-species of C3 mRNA in all cultures. Analysis with laser densitometry showed that the content of $\mathrm{C} 3 \mathrm{mRNA}$ was increased 2.0 \pm 0.5 -fold after stimulation with IL-2 for $24 \mathrm{~h}$ and a significant increase of $3.5 \pm 0.2$-fold was seen at $72 \mathrm{~h}(P$ $<0.01$ ), suggesting a pretranslational control by IL-2. The amount of $\beta$-actin mRNA was comparable in all cultures (Fig. 6). These findings at the RNA level are in agreement with the results already found at the protein level. To confirm that the regulation of $\mathrm{C} 3$ production by PTEC is a specific property of IL-2, antibody blocking experiments were performed. Therefore $F\left(a b^{\prime}\right)_{2}$ fragments of rabbit IgG anti-human IL-2 and normal rabbit IgG were used to prevent any possible Fc interaction on PTEC. Replicate PTEC monolayers were cultured in the presence of IL-2 and/or the various antibodies. The results in Fig. 7 demonstrate a $74 \%$ increase in $\mathrm{C} 3$ production after IL-2 treatment as compared with medium alone. Addition of $\mathrm{F}\left(\mathrm{ab}^{\prime}\right)_{2}$ fragments of rabbit IgG anti-human IL-2 to the IL-2-stimulated cultures completely neutralized the regulating effect of IL-2, whereas $F\left(a b^{\prime}\right)_{2}$ fragments of normal rabbit IgG had no effect. One way analysis of variance showed that there was no

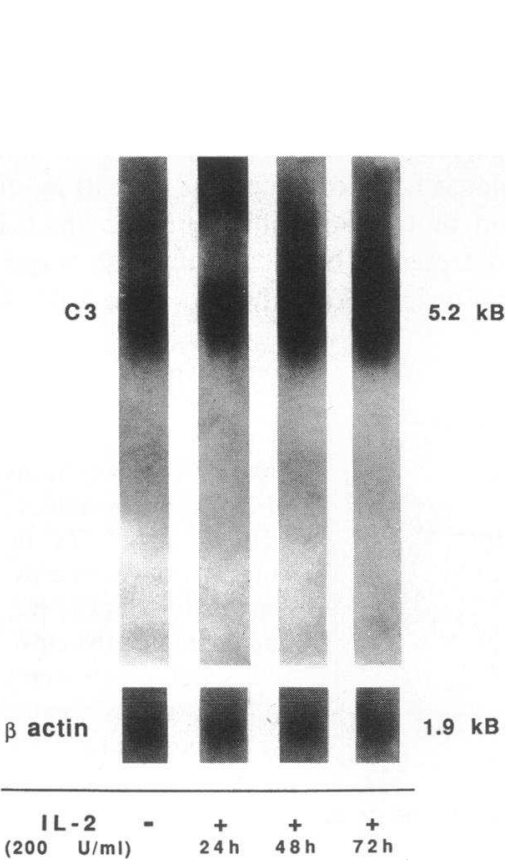

Figure 6. Northern blot analysis of the effect of IL-2 on the expression of C3 mRNA by PTEC in culture. Cells were incubated in the presence of $200 \mathrm{U} / \mathrm{ml} \mathrm{IL-2}$ $(+)$ or in medium alone $(-)$. After 24, 48, and $72 \mathrm{~h}$ of IL-2 treatment total RNA was isolated, and from each culture $20 \mu \mathrm{g}$ RNA were electrophoresed, blotted, and hybridized. The upper row shows hybridization to a human $\mathrm{C} 3$ cDNA probe, whereas the lower row shows hybridization to a $\beta$-actin probe. The figure shows one representative Northern blot analysis of three separate experiments.

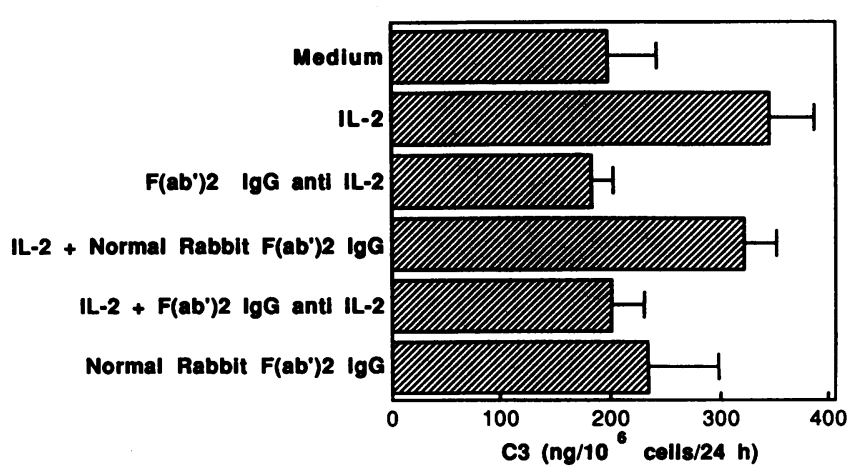

Figure 7. Effect of rabbit anti-human IL-2 on IL-2-mediated C3 production by PTEC. PTEC were incubated with IL-2 $(200 \mathrm{U} / \mathrm{ml})$, IL-2 together with $\mathrm{F}\left(\mathrm{ab}^{\prime}\right)_{2}$ fragments of rabbit IgG anti-IL-2 (1:250), $F\left(a b^{\prime}\right)_{2}$ anti-IL-2, or $F\left(a b^{\prime}\right)_{2}$ fragments of normal rabbit IgG. After 72 $h$, culture supernatants were harvested and analyzed for C3. Values represent the mean $\pm \mathrm{SD}$ of duplicate determinations of quadruplicate cultures.

significant difference between all controls and the IL-2-neutralized culture and that the difference between controls and IL-2-stimulated cultures was significant $(P<0.01)$.

The response to IL-2 suggests the presence of a receptor for IL-2 on PTEC, therefore, binding experiments were performed using radiolabeled IL-2. Monolayers of PTEC were incubated with $20 \mathrm{nM}$ of ${ }^{125} \mathrm{I}-\mathrm{IL}-2$ alone or in the presence of increasing concentrations of unlabeled IL-2. Results of IL-2 binding to PTEC are shown in Table I. Inhibition of ${ }^{125} \mathrm{I}-\mathrm{IL}-2$ binding to PTEC by unlabeled IL-2 indicates that specific binding of IL-2 occurs to PTEC, whereas under identical conditions no signifcant binding of radiolabeled IL-2 to EC was observed.

\section{Discussion}

The complement system plays an important role in the humoral immune response. Several studies have shown that hepatocytes in the liver are the main site for systemic complement synthesis. However, many of the complement components are also synthesized by other cell types at extrahepatic sites, such as mononuclear phagocytes (27), fibroblasts (7), and epithelial cells of the lung (11) and intestine (28). In the case of

Table I. Binding of ${ }^{125}$ I-IL-2 to Proximal Tubular Epithelial Cells

\begin{tabular}{lcc}
\hline Cells & Inhibitor & Bound radioactivity* \\
\hline & & $c p m$ \\
PTEC & - & $5227 \pm 396$ \\
PTEC & $20 \mathrm{nM} \mathrm{IL-2}$ & $4322 \pm 286$ \\
PTEC & $200 \mathrm{nM} \mathrm{IL-2}$ & $1605 \pm 206$ \\
EC & - & $348 \pm 54$ \\
EC & $20 \mathrm{nM}$ IL-2 & $378 \pm 81$ \\
EC & $200 \mathrm{nM} \mathrm{IL-2}$ & $302 \pm 39$
\end{tabular}

* Monolayers of PTEC and human EC as control, cultured in 24-well tissue culture plates, were incubated in quadruplicate for $1 \mathrm{~h}$ at $4^{\circ} \mathrm{C}$ with various concentrations of ${ }^{125} \mathrm{I}$-IL-2 alone or in the presence of unlabeled IL-2. Cells were then washed and assessed for bound radioactivity. 
several renal diseases, complement deposits associated with immune complexes are found in the kidney. However, it has been demonstrated that complement components can be found without deposition of immunoglobulins (29), suggesting a possible local production of complement in the kidney. Indeed, it has been demonstrated that C4 mRNA is expressed in normal human kidney (12). Previously, Passwell et al. (13) observed a higher expression of $\mathrm{C} 2, \mathrm{C} 3, \mathrm{C} 4$, and factor $\mathrm{B}$ mRNA in a SLE-sensitive mouse strain compared with normal mice that correlated with macrophage infiltrates. But in these studies it still remained unclear which cell type was responsible for the local complement production. In this study it is demonstrated that human PTEC synthesize and secrete complement $\mathrm{C} 3$ in vitro and this synthesis is regulated by IL-2. Studies were performed with more than 20 cell lines obtained from 8 different kidneys. The amount of $\mathrm{C} 3$ produced by these cells was between 89 and $210 \mathrm{ng} / 10^{6}$ cells per $24 \mathrm{~h}$, however, in all of these cell lines IL- 2 was able to enhance $\mathrm{C} 3$ production to the same relative extent. Reasons for the variation in the amount of $\mathrm{C} 3$ produced is not clear at present. No relationship with clinical conditions of the kidney donor was found. However, it was observed that the production of $\mathrm{C} 3$ decreased gradually after repeated passages, therefore, experiments were done using PTEC between passage 2 and 6 . The size and subunit structure of C3 produced in PTEC were similar to that observed in both Hep-G2 cells (24) and in human monocytes (6). The functional activity of PTEC-C3 increased linearly with time and was comparable to plasma C3. During culturing, however, there is probably a partial inactivation of the $\mathrm{C} 3$ molecule. Addition of IL-2 to the cultures increased synthesis of $\mathrm{C} 3$ in a dose-dependent fashion, with a maximal 2.5-fold increase above the baseline rate of $\mathrm{C} 3$ production (Fig. 4). The effect of IL-2 was also studied at the mRNA level using Northern blot analysis, demonstrating that the increase in rate of $\mathrm{C} 3$ protein synthesis after IL-2 treatment correlated with the increase in C3 mRNA levels. This suggests that IL-2 regulated C 3 synthesis at a pretranslational level. Blocking studies with neutralizing antibodies to IL-2 demonstrated that the effects mediated by IL-2 on C3 production was specific for this cytokine. The ability of human PTEC to respond to IL-2 indicates the presence of a functional receptor for IL-2 on these cells. Indeed, in this study it was found that radiolabeled IL-2 bound to PTEC and the binding could be inhibited by unlabeled IL-2, suggesting that IL-2 was specifically associated with PTEC (Table I). Nevertheless, with FACS $^{\circledR}$ (Becton Dickinson \& Co., Mountain View, CA) analysis the expression of IL-2 receptor- $\alpha$, which is recognized by the Tac MAb (30), could not be demonstrated under the same conditions (data not shown). This could mean that the expression of IL- 2 receptor- $\alpha$ is low or that only the IL- 2 receptor- $\beta$ is present, as has been described recently for human monocytes (31). Characterisation of the IL-2 receptors on PTEC is currently in progress.

IL-2 has the ability to induce the synthesis of IFN- $\gamma$, IL-1, lymphotoxin, and tumor necrosis factor by PBMC in vitro (32, 33), this could mean that in PTEC, for instance, IL-2 also induces other cytokines that could be responsible for the observed effects. Cancer patients receiving high dose IL-2 treatment develop marked changes in serum concentrations of complement proteins (34). It has been suggested that this effect of IL-2 on hepatic synthesis is mediated by IL-1 (35). Studies have demonstrated that the cells that infiltrate renal allografts during rejection include alloproliferative, IL-2 producing T lymphocytes (36). Whether there are more complement components synthesized by PTEC and whether other mediators are also involved in regulation of tissue specific complement production is currently under investigation.

This study indicates that PTEC synthesize reasonable amounts of C3 that could play a possible role in the pathogenesis of renal inflammation caused by immune complexes. Further studies using isolated kidney cell preparations of other types, such as mesangial cells and glomerular epithelial cells and studies on kidney material in situ, are needed to determine whether local complement synthesis correlates with disease activity.

\section{Acknowledgments}

The authors would like to thank Marjon Kluiters for her help in the preparation of the manuscript.

This study was supported in part by the Dutch Medical Research Council, which is subsidized by the Netherlands Organisation for Scientific Research.

\section{References}

1. Lambris, J. D. 1988. The multifunctional role of $\mathrm{C} 3$, the third component of complement. Immunol. Today. 9:387-393.

2. Tack, B. F., S. C. Morris, and J. W. Prahl. 1979. Third component of human complement: structural analysis of the polypeptide chains of $\mathrm{C} 3$ and $\mathrm{C} 3 \mathrm{~b}$. Biochemistry. 18:1497-1503.

3. Alper, C. A., A. M. Johnson, A. G. Birtch, and F. D. Moore. 1969. Human C3: evidence for the liver as the primary site of synthesis. Science (Wash. DC). 163:286-288.

4. Johnson, E., and G. Hetland. 1988. Mononuclear phagocytes have the potential to synthesize the complete functional complement system. Scand. J. Immunol. 27:489-493.

5. Whaley, K. 1980. Biosynthesis of the complement components and the regulatory proteins of the alternative complement pathway of human peripheral blood monocytes. J. Exp. Med. 151:501-516.

6. Beatty, D. W., A. E. Davis, F. Sessions Cole, L. P. Einstein, and H. R. Colten. 1981. Biosynthesis of complement by human monocytes. Clin. Immunol. Immunopathol. 18:334-343.

7. Katz, Y., and R. C. Strunk. 1988. Synovial fibroblast-like cells synthesize seven proteins of the complement system. Arthritis Rheum. 31:1365-1370.

8. Warren, H. B., P. Panzaris, and P. F. Davis. 1987. The third component of complement is transcribed and secreted by cultured human endothelial cells. Am. J. Pathol. 129:9-13.

9. Ueki, A., T. Sai, H. Oka, T. Tabata, K. Hosokawa, and Y. Mochizuki. 1987. Biosynthesis and secretion of the third component of complement by human endothelial cells in vitro. Immunology. 61:11-14.

10. Brooimans, R. A., P. S. Hiemstra, A. A. J. van der Ark, R. B. Sim, L. A. van Es, and M. R. Daha. 1989. Biosynthesis of complement factor $H$ by human umbilical vein endothelial cells: Regulation by T cell growth factor and IFN- $\gamma . J$. Immunol. 142:2024-2030.

11. Strunk, R. C., D. M. Eidlen, and R. J. Mason. 1988. Pulmonary alveolar type II epithelial cells synthesize and secrete proteins of the classical and alternative complement pathways. J. Clin. Invest. 81:1419-1426.

12. Feucht, H. E., J. Zwirner, D. Bevec, M. Lang, E. Felber, G. Riethmuller, and E. H. Weiss. 1989. Biosynthesis of complement C4 messenger RNA in normal human kidney. Nephron. 53:338-342.

13. Passwell, J., G. F. Schreiner, M. Nonaka, H. U. Beuscher, and H. R. Colten. 1988. Local extrahepatic expression of complement genes C3, factor B, $\mathrm{C} 2$, and $\mathrm{C4}$ is increased in murine lupus nephritis. J. Clin. Invest. 82:1676-1684.

14. Zwirner, J., E. Felber, V. Herzog, G. Riethmüller, and H. E. Feucht. 1989. Classical pathway of complement activation in normal and diseased human glomeruli. Kidney Int. 36:1069-1077.

15. Roord, J. J., M. R. Daha, W. Kuis, H. A. Verbrugh, J. Verhoef, B. J. M. Zegers, and J. W. Stoop. 1983. Inherited deficiency of the third component of complement associated with recurrent pyogenic infections, circulating immune complexes, and vasculitis in a Dutch family. Pediatrics. 71:81-87.

16. Hack, C. E., J. Paardekooper, R. J. T. Smeenk, J. Abbink, A. J. M. Eerenberg, and J. H. Nuijens. 1988. Disruption of the internal thioester bond in the third component of complement (C3) results in the exposure of neodeterminants also present on activation products of C3. J. Immunol. 141:1602-1609.

17. Stanworth, D. R., and M. W. Turner. 1978. Immunochemical analysis of immunoglobulins and their sub-units. In Handbook of Experimental Immunol- 
ogy. Vol. 1, Immunochemistry. 3rd ed. D. M. Weir, editor. Blackwell Scientific Publications Ltd., Oxford. 6.1-6.40.

18. Miltenburg, A. M. M., M. E. Meijer-Paape, M. R. Daha, J. H. van Bockel, J. J. Weening, L. A. van Es, and F. J. van der Woude. 1989. Donor-specific lysis of human epithelial cells by renal allograft-infiltrating lymphocytes. Transplantation. 48:296-302.

19. Detrisac, C. J., M. A. Sens, A. J. Garvin, S. S. Spicer, and D. A. Sens. 1984 Tissue culture of human kidney epithelial cells of proximal tubule origin. Kidney Int. 25:383-390.

20. Borsos, T., H. J. Rap, and M. M. Mayer. 1961. Studies on the second component of complement. J. Immunol. 87:310-325.

21. Chirgwin, J. M., A. E. Przybyla, R. J. MacDonald, and W. J. Rutter. 1979. Isolation of biologically active ribonucleic acid from sources enriched in ribonuclease. Biochemistry. 18:5294-5299.

22. Maniatis, T., E. F. Fritsch, and J. Sambrook. 1982. Molecular Cloning. A laboratory manual. Cold Spring Harbor Laboratory. Cold Spring Harbor, New York.

23. Feinberg, A. P., and B. Vogelstein. 1983. A technique for radiolabeling DNA restriction endonuclease fragments to high specific activity. Anal. Biochem. 132:6-13.

24. Morris, K. M., G. Goldberger, H. R. Colten, D. P. Aden, and B. B. Knowles. 1982. Biosynthesis and processing of a human precursor complement protein, pro-C3, in a hepatoma-derived cell line. Science (Wash. DC). 215:399400.

25. Katz, Y., M. Revel, and R. C. Strunk. 1989. Interleukin 6 stimulates synthesis of complement proteins factor $\mathrm{B}$ and $\mathrm{C} 3$ in human skin fibroblasts. Eur. J. Immunol. 19:983-988.

26. Sim, R. B., and E. Sim. 1981. Autolytic fragmentation of complemen components $\mathrm{C} 3$ and $\mathrm{C} 4$ under denaturating conditions, a property shared with $a$ 2-macroglobulin. Biochem. J. 193:129-141.

27. Cole, F. S., H. S. Auerbach, G. Goldberger, and H. R. Colten. 1985
Tissue-specific pretransplantational regulation of complement production in human mononuclear phagocytes. J. Immunol. 134:2610-2616.

28. Morris, K. M., H. R. Colten, and D. H. Bing. 1978. The first component of complement. A quantitative comparison of its biosynthesis in culture by human epithelial and mesenchymal cells. J. Exp. Med. 148:1007-1019.

29. Hinglais, N., M. D. Kazatchkine, S. Bhakdi, M.-D. Appay, Ch. Mandet, J. Grossetete, and J. Bariety. 1986. Immunohistochemical study of the C5b-9 complex of complement in human kidneys. Kidney Int. 30:399-410.

30. Waldmann, T. A. 1986. The structure, function and expression of interleukin 2 receptors on normal and malignant lymphocytes. Science (Wash. DC) 232:727-729.

31. Espinoza-Delgado, I., J. R. Ortaldo, R. Winkler-Pickett, K. Sugamura, L. Varesio, and D. L. Longo. 1990. Expression and role of p75 interleukin 2 receptor on human monocytes. J. Exp. Med. 171:1821-1826.

32. Handa, K., R. Suzuki, H. Matsue, Y. Shimizu, and K. Kumagai. 1983. Natural killer (NK) cells as a responder to interleukin-2 (IL-2). II. IL-2-induced interferon- $\gamma$ production. J. Immunol. 130:988-992.

33. Nedwin, G. E., L. P. Svedersky, T. S. Bringman, M. A. Palladino, and D. V. Goeddel. 1985. Effect of interleukin 2, interferon- $\gamma$ and mitogens on the production of tumor necrosis factor $\alpha$ and $\beta$. J. Immunol. 135:2492-2497.

34. Atkins, M. B., J. A. Gould, M. Allegrata, R. A. Dempsey, R. A. Rudders, D. R. Parkinson, and W. J. Mier. 1986. Phase I evaluation of recombinant interleukin-2 in patients with advanced malignant disease. J. Clin. Oncol. 4:13801386.

35. Mier, J. W., C. A. Dinarello, M. B. Atkins, P. I. Punsal, and D. H. Perlmutter. 1987. Regulation of hepatic acute phase protein synthesis by products of interleukin 2 (IL-2) stimulated human peripheral blood mononuclear cells. $J$. Immunol. 139:1268-1272.

36. Preffer, F. I., R. B. Colvin, C. P. Leary, L. A. Boyle, T. V. Tuazon, A. I Lazarovits, A. B. Cosimi, and J. T. Kurnick. 1986. Two-color flow cytometry and functional analysis of lymphocytes cultured from human renal allografts: identification of a leu- $2^{+} 3^{+}$subpopulation. J. Immunol. 137:2823-2830. 